\title{
Article
}

\section{Photoactive plants: Botany bad boys or horticultural heroes?}

\begin{abstract}
Wainwright, Mark, Stockburn, William, Lawrence, Clare Louise, Stevens, Harry J., Jones, Allison Elizabeth and Smith, Robert B

Available at http://clok.uclan.ac.uk/21072/

Wainwright, Mark, Stockburn, William ORCID: 0000-0002-2351-2776, Lawrence, Clare Louise ORCID: 0000-0003-0170-0079, Stevens, Harry J., Jones, Allison Elizabeth ORCID: 0000-0002-9677-3950 and Smith, Robert B ORCID: 0000-0002-2829-5360 (2018) Photoactive plants: Botany bad boys or horticultural heroes? Phytotherapy Research, 32 (3). pp. 561-563. ISSN 0951$418 X$
\end{abstract}

It is advisable to refer to the publisher's version if you intend to cite from the work. http://dx.doi.org/10.1002/ptr.5997

For more information about UCLan's research in this area go to http://www.uclan.ac.uk/researchgroups/ and search for <name of research Group>.

For information about Research generally at UCLan please go to http://www.uclan.ac.uk/research/

All outputs in CLoK are protected by Intellectual Property Rights law, including Copyright law. Copyright, IPR and Moral Rights for the works on this site are retained by the individual authors and/or other copyright owners. Terms and conditions for use of this material are defined in the policies page.

\section{CLoK}

Central Lancashire online Knowledge www.clok.uclan.ac.uk

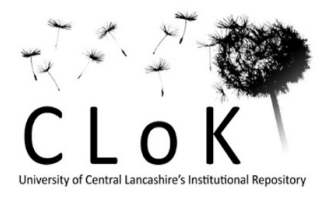


Photoactive Plants - Botany Bad Boys or Horticultural Heroes?

Mark Wainwright ${ }^{1}$, William J. Stockburn ${ }^{2}$, Clare L. Lawrence ${ }^{3}$, Harry J. Stevens ${ }^{4}$, Allison E. Jones ${ }^{5}$ and Robert B. Smith ${ }^{*}$

${ }^{1}$ School of Pharmacy \& Biomolecular Sciences, Liverpool John Moores University, Liverpool, L3 3AF, United Kingdom

${ }^{2}$ School of Forensic and Applied Science, University of Central Lancashire, Preston, PR1 2HE, United Kingdom

${ }^{3}$ School of Pharmacy and Biomedical Sciences, Faculty of Clinical and Biomedical Sciences, University of Central Lancashire, Preston, PR1 2HE

${ }^{4}$ School of Physical Sciences and Computing, University of Central Lancashire, Preston, PR1 2HE, United Kingdom

${ }^{5}$ Faculty of Science and Technology, University of Central Lancashire, Preston, PR1 2HE, United Kingdom

*Author for correspondence - rbsmith@uclan.ac.uk, Tel: +44 (0) 1772894384 


\section{Introduction}

Recent media reports across the United Kingdom (Baker et al. 2017) have highlighted the injury caused to both people and animals on exposure to giant hogweed (Heracleum mantegazzianum), reminding us of the power of plant metabolites. What was not emphasised in these reports was the fact that sunlight is an essential part of the equation; the rather painful outcome of this combination being a condition known as phytophotodermatitis. As far back as 1916, Freund noted the appearance of skin lesions on people who had been in contact with bergamot oil in perfume and had been exposed to the sun. Today this is referred to as berloque dermatitis (Kavli et al. 1984). In 1934, similarly, Oppenheim noted a link between sunbathers who had been lying in grass and erythema, which he described as dermatitis bullosa striata pratensis (meadow grass dermatitis) (Pathak 1986). Indeed, the term was first coined by Klaber (1942) and is best defined as a phototoxic dermal reaction caused by the interaction of plant material, sunlight and human skin.

The chemistry or - more accurately - the photochemistry behind such reactions is relatively straightforward. Some of the chemicals in plants, such as $H$. mantegazzianum are heteroaromatic in nature (i.e. delocalised $\pi$-systems containing heteroatoms) and can absorb ultraviolet light. Examples such as psoralen (furocoumarin, Figure 1) absorb long wavelength UV-A (315-400 nm) and can use this energy to elevate electrons from the ground electronic singlet state to the singlet excited state, either for use in forming new covalent bonds with other molecules such as DNA $(2+2$ photochemical reaction), or in producing reactive oxygen species (ROS) via electron or energy transfer to in situ oxygen from the triplet excited state (Type I or Type II photosensitisation pathways, Box 1).

\section{The Rutaceae or Umbelliferae Families}

Phytophotodermatitis is often associated with plants belonging to either the Rutaceae or Umbelliferae families, due to their popularity in everyday culinary use. Rutaceae spp. include plants such as limes (Citrus acida), lemons (Citrus limon), grapefruit (Citrus paradise) and bergamot (Citrus bergamia), While the Umbelliferae family consists of dill (Anethum graveolens), celery (Apium graveolens), garden carrot (Daucus sativus), sweet fennel (Foeniculum vulgare), parsnip (Pastinaca sativa) and parsley (Petroselinum crispum). Incidences of phytophotodermatitis associated with the Rutaceae family include perioral dermatitis, resulting from sucking on a lime after drinking an alcoholic beverage. Similarly, phytophotodermatitis can be observed on the hands of bartenders who use limes and lemons in their cocktails or among those who make fresh lemonade (Janda et al. 2008). These recreational injuries may be 'powered' by direct sunlight or internal ultraviolet lighting. The application of Rue (Ruta graveolens) as an insect repellent has also been noted to cause phytophotodermatitis (Eickhorst et al. 2007), as has the wearing of Hawaiian leis (as neck garlands) made of the fruits of Pelea anisata (Elpern, et al. 1984). As noted, phytophotodermatitis is often attributed to the ultraviolet-absorbing furocoumarins, which have both photochemical and photodynamic activities when exposed to light of the correct wavelength. The furocoumarins, shown in Figure 1, are linear or angular tricyclic oxygen heterocycles (psoralens and angelicins respectively) which may react directly with unsaturated biomolecules (e.g. lipids, not just DNA) or may produce short-lived ROS which are damaging to cells via oxidative mechanisms. 


\section{Photosensitisation}

Contact skin photosensitisation of this type is a relatively common event in modern life (Pfurtscheller et al 2014), whether from exposure to plants, such as hogweed, or to food crops such as citrus or celery. Similarly, the ingestion of large amounts of such plants by ruminant animals allows the concentration of fat-soluble photosensitisers in the dermis to increase, resulting in subsequent photodamage to the animal (Quinn, et al. 2014). Such issues have also been reported in Nordic countries where the photosensitisation of lambs on pasture ('alveld' or 'elf fire'), is caused by the ingestion of bog asphodel (Narthecium ossifragum) (Ingebrigtsen, 2008). Hypericism is a well-known complaint associated with cattle, named for the plant Hypericum perforatum (St John's Wort) and its red light-absorbing photosensitiser hypericin, though is not exclusively associated with this (Giese, 1980).

As with other natural product sources, we can utilise this associated destructive power for our own benefit, as demonstrated daily in the clinical treatment of psoriasis and other skin disorders, with psoralens and long wavelength ultraviolet light (ultraviolet A, thus "PUVA" therapy). Whilst such approaches have been known for millennia, the use of natural products remains more acceptable in medicine than does that of total synthetics. In addition, the novel modes of action demonstrated by these "natural absorbers" offer new ways to kill other target cells, whether these are cancerous tumours or pathogenic microbes (Dolmans et al. 2003).

\section{Antimicrobial Resistance vs Mother Nature's Photoactive Toolbox}

With the rapid development of antimicrobial resistance and the lack of novel drugs coming into the clinic, it's becoming ever more important that we maintain infection control whist conserving effective conventional antimicrobial agents (Wainwright, 2012). To this end, it's highly plausible that photoactive plants could hold the answer due to their inbuilt photoactive defence systems. ROS produced on illumination, such as the hydroxyl radical or singlet oxygen are highly damaging to microbial cells causing lysis within a matter of seconds via the mechanistic pathways shown in Box 1 (Wainwright et al., 2017). Target selectivity could also be maintained if applied topically and directly to the site of the infection.

In 2013, the UK's Chief Medical Officer addressed the UK parliament and informed its members that

'“Antimicrobial resistance poses a catastrophic threat. If we don't act now, any one of us could go into hospital in 20 years for minor surgery and die because of an ordinary infection that can't be treated by antibiotics". In 2014, the World Health Organisation (WHO) published a report highlighting the significant rise in antimicrobial resistance around the globe. The WHO worryingly predicted a situation where common infections and small injuries will once again bring death in a post-antibiotic era (The Alliance to Save Our Antibiotics, 2014). The recently published O'Neill Report (commissioned by the UK government) makes similar predictions (O'Neill, 2015).

\section{Conclusion}

Antimicrobial resistance presents a gigantic challenge to society. We cannot simply look for new synthetic variations of established drugs, but must look towards new, technological solutions. Mother Nature's toolbox is full of such antimicrobial assassins and some of these pack an impressive 'light punch' unlike any current 
drug on the market. Our response to this truly worrying situation in healthcare must surely include a close look at photoactive plant chemicals and their thorough investigation in order to combat resistant microbial disease. 


\section{References}

Antimicrobial resistance - why the irresponsible use of antibiotics in agriculture must stop. The Alliance to Save Our Antibiotics. June 2014.

Baker, B.G. et al. 2017. Keeping pace with the media; Giant Hogweed burns - A case series and comprehensive review. Burns, 45: 933-938.

Dolmans, D.E.J.G.J. et al. 2003. Photodynamic therapy for cancer. Nature Reviews Cancer, 3: 380-387.

Eickhorst, K. et al. 2007. Rue the herb: Ruta graveolens—associated phytophototoxicity. Dermatitis. 18: 525.

Elpern, D.J. and Mitchell, J.C. 1984. Phytophotodermatitis from mokihana fruits (Pelea anisata H. Mann, fam. Rutaceae) in Hawaiian lei. Contact Dermatitis. 10: 224-226.

Giese, A.C. 1980. Hypericism, Photochemical and Photobiological Reviews 229-255.

Ingebrigtsen, K. 2008. Main plant poisonings in livestock in the Nordic countries. Bioactive compounds in plants -benefits and risks for man and animals, 30-43.

Janda, P.H. et al. 2008. Main plant poisonings in livestock in the Nordic countries: Case Report and Review of the Literature. Cosmetic Dermatology. 21: 99-103.

Kavli, G. Volden, G. 1984. Phytophotodermatitis. Photodermatol.1: 65-75.

Klaber R. 1942. Phyto-photo-dermatitis. Br J Dermatol. 54: 117-118.

O'Neill J. 2015. Review on antimicrobial resistance. Securing new drugs for future generations: the pipeline of antibiotics. Available at: http://bit.ly/1JKCGvw.

Pathak, M.A. 1986. Phytophotodermatitis. Clin Dermatol. 4: 102-121.

Pfurtscheller K. Trop M. 2014. Phototoxic plant burns: report of a case and review of topical wound treatment in children.Pediatr Dermatol. 31: 156-159

Quinn, J.C. et al. 2014. Secondary Plant Products Causing Photosensitization in Grazing Herbivores: Their Structure, Activity and Regulation. Int. J. Mol. Sci. 15: 1441-1465.

Wainwright, M. 2012. Photodyanimic Medicine and Infection Control, J. Antimicrob. Chemother. 67: 787-788. Wainwright $\mathrm{M}$ et al. 2017. Photoantimicrobials: Are we afraid of the light? Lancet Infect. Dis. 17: e49-e55. 


\section{Figures}<smiles>O=c1ccc2cc3ccoc3cc2o1</smiles>

Psoralen<smiles>COc1c2ccoc2cc2oc(=O)ccc12</smiles>

Bergapten<smiles>O=c1ccc2ccc3occc3c2o1</smiles>

Angelicin<smiles>COc1c(OC)c2occc2c2oc(=O)ccc12</smiles>

Pimpinellin

Figure 1: Parent furocoumarins, psoralen and angelicin, and other examples, bergapten and pimpinellin, found in the Giant Hogweed 


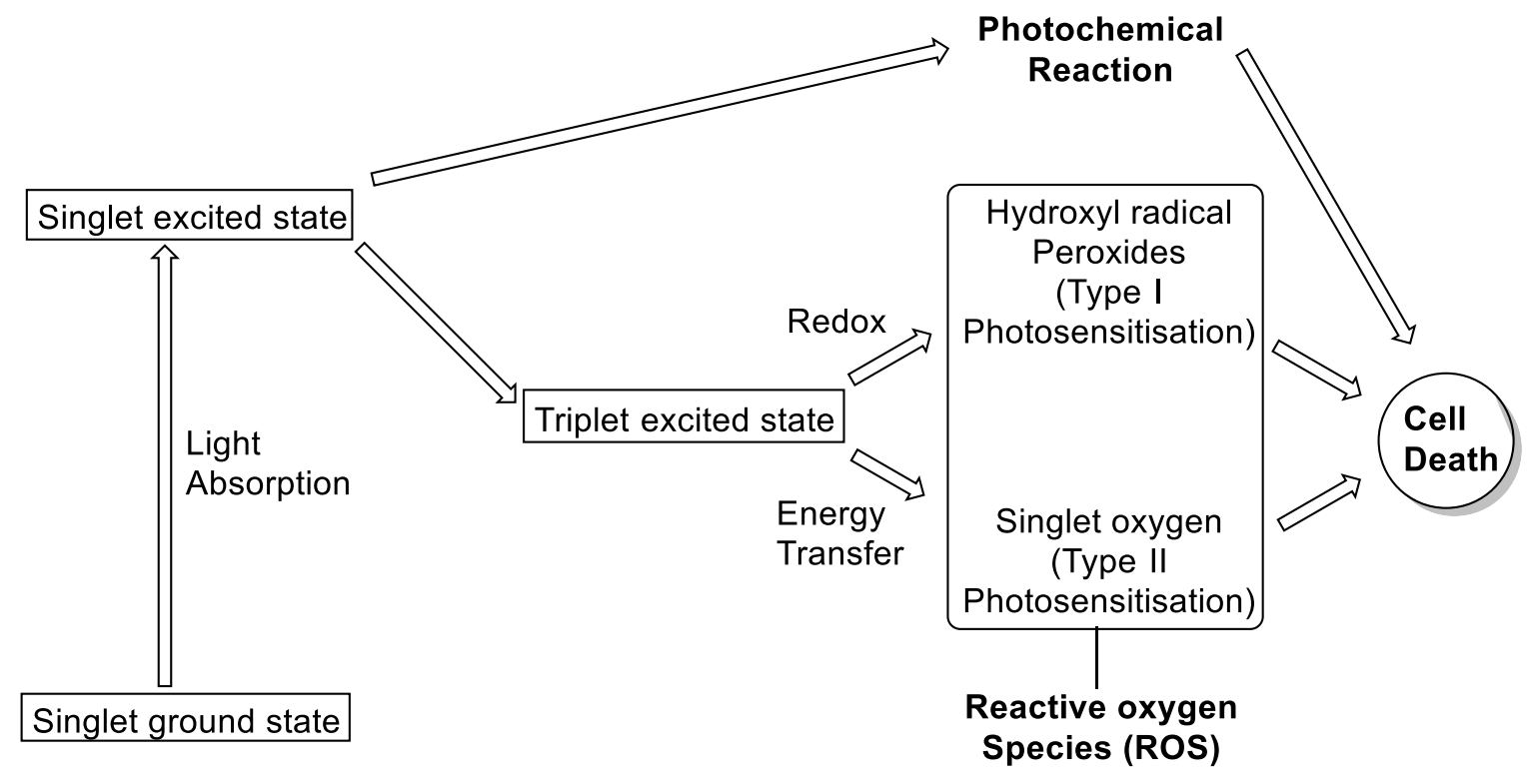

Photosensitiser

At target site

Box 1: The Photoactive Mechanistic Pathway 